\title{
PERAN PROGRAM BETULUNGAN BEBERSEH KAMPONG DALAM PERILAKU MASYARAKAT TERKAIT PENGELOLAAN SAMPAH DI KECAMATAN ANGGANA KABUPATEN KUTAI KARTANEGARA
}

\author{
Ihsan Tri Rengganis ${ }^{1}$, Riana Rahmaningrum², RSDMG Luhur ${ }^{3}$ \\ ${ }^{1}$ Community Development Offier PT Pertamina Hulu Mahakam Lapangan CPU \\ 2 CSR Officer PT Pertamina Hulu Mahakam Lapangan CPU \\ 3 Head Service of Environment, Health and Philantrophy PT Pertamina Hulu Mahakam Lapangan CPU \\ Email: ihsantrir@gmail.com
}

\begin{abstract}
Waste is serious problem produced by 250 million Indonesian and it worsened by the ineffective governance that leads to mismanaged waste. According to BPS, $62 \%$ of trash volume produced by household level which only $1,2 \%$ of them is recycled while the most of the rest is being burned down. Trash volume would increase along with human population, without proper management this problem would likely caused cathasthrope in the future. This research aimed to know about the role of Gerakan Bersih Kecamatan Anggana-Bank Sampah Central Anggana (GBKA-BSCA), social group formed by SKK Migas PT Pertamina Hulu Mahakam, to promote clean and healthy lifestyle or Perilaku Hidup Sehat (PHBS) and waste management in regency level which held in Kecamatan Anggana Kabupaten Kutai Kartanegara Provinsi Kalimantan Timur. This quantitative research used crossectional designed to compare methods to compare the behaviour of waste bank costumer and noncostumer. Qualitative approach such as observation and deep interview was used to be completing data of this research. Result founded that there were significant difference between experiment group and control in way of non organic waste culling and open burning frequency in household level with 0,000 significancy number.
\end{abstract}

Keywords: Waste Bank, Household Trash, Behavioural Change, Corporate Social Responsibility

\begin{abstract}
Abstrak
Aktivitas hidup lebih dari 250 juta orang penduduk Indonesia menimbulkan masalah serius yaitu tumpukan sampah yang diperparah dengan pengelolaan yang buruk. Menurut data BPS (Badan Pusat Statistik) Indonesia, besaran sampah rumah tangga memenuhi $62 \%$ dari total sampah yang ada di Indonesia, dari angka tersebut hanya $1,2 \%$ yang mendaur ulang sampah sedangkan mayoritas rumah tangga di Indonesia memusnahkan sampah dengan cara dibakar. Jumlah sampah turut bertumbuh dengan peningkatan jumlah populasi, tanpa adanya pengelolaan yang tepat dapat memicu bencana iklim di masa yang akan datang. Penelitian ini bermaksud untuk mengetahui peranan Gerakan Bersih Kecamatan Anggana-Bank Sampah Central Anggana (GBKA-BSCA), kelompok binaan SKK Migas - PT Pertamina Hulu Mahakam, dalam usaha edukasi Perilaku Hidup Sehat (PHBS) dan pengelolaan sampah di Kecamatan Anggana Kabupaten Kutai Kartanegara Provinsi Kalimantan Timur. Penelitian ini merupakan penelitian kuantitatif dengan desain crossectional yang bertujuan untuk membandingkan perilaku nasabah GBKA-BSCA dan kelompok non-nasabah. Pendekatan kualitatif seperti pengamatan dan wawancara mendalam dilakukan untuk melengkapi data penelitian ini menjadi satu kesatuan yang utuh. Hasilnya terdapat perbedaan perilaku yang signifikan antara kelompok kontrol dan kelompok eksperimen pada cara pemusnahan sampah non organik dan frekuensi pembakaran sampah dengan signfikansi sebesar 0,000.
\end{abstract}

Kata kunci: Bank Sampah, Sampah Rumah Tangga, Perubahan Perilaku, Corporate Social Responsibility

\section{Pendahuluan}

Sampah adalah bahan buangan dari sisa kegiatan rumah tangga, komersial, industri maupun aktivitas manusia lainnya yang sudah tidak lagi terpakai dan tidak lagi diinginkan oleh pemiliknya (Puwendro \& Nurhidayat, 2006). Dengan kata lain sampah merupakan efek samping yang selalu ada di dalam setiap kegiatan yang dilakukan oleh makhluk hidup terutama manusia. SK SNI T-13-1990-F menambahkan bahwa sampah terdiri dari zat organik dan anorganik, dianggap tidak berguna dan harus dikelola agar tidak membahayakan lingkungan serta melindungi investasi pembangunan. Sehingga merupakan kewajiban kita dalam pengelolaan hasil sampah buangan agar tidak mencemari lingkungan maupun merusak kesehatan manusia. 
Indonesia berada dalam posisi kedua sebagai negara yang paling banyak membuang sampahnya ke lautan. Sampah plastik yang dihasilkan perharinya 11 juta kilogram, namun akibat managemen pengelolan sampah yang buruk jumlah mismanaged waste mencapai 9 juta kilogram. Posisi pertama ditempati Tiongkok yang menghasilkan 32 juta kilogram sampah per hari dengan jumlah sampah yang tak terkelola sebanyak 24 juta kilogram. Sedangkan Amerika Serikat menghasilkan 38 juta kilo sampah setiap harinya namun jumlah mismanaged waste-nya minim (J. Jambeck, 2015). Indonesia bukanlah penghasil sampah terbanyak di dunia, namun masalahnya terletak pada kesalahan manajeman tata kelola sampah.

Selain menimbulkan permasalahan di dalam aspek lingkungan, sampah juga dapat mengganggu kesehatan manusia secara tidak langsung melalui pencemaran udara, air dan tahah diakibatkan dari sistem manajemen pengelolaan sampah yang tidak tepat. Pengelolaan sampah harus dilakukan sesuai dengan jenis sampahnya sehingga meminimalkan dampak yang ditimbulkan. Beberapa penyakit ringan diakibatkan oleh sampah secara instan adalah jika kontak langsung dengan tanah dapat meningkatkan resiko soil borne disease seperti cacingan, jika terkena air dapat memicu resiko water borne disease seperti diare dan alergi. Namun yang paling fatal dan tidak disadari adalah apabila gangguan kesehatan ditimbulkan akibat terlalu lama terpapar zat zat tertentu yang tidak disadari dalam kurun waktu yang lama sehingga berpotensi untuk resiko keracunan logam berat serta hepatitis dan juga resiko air borne disease seperti asma, sesak nafas dan kerusakan paru. Timbunan sampah organik yang terpapar panas menjadi tempat berkembang biaknya mikroba, serangga dan hewan pengerat. Secara tidak langsung sampah memicu timbulnya penyakit yang dibawa oleh nyamuk (vektor borne disease) dan tikus (rondent borne disease) seperti demam berdarah dan leptospirosis (Moelyaningrum, 2019).

Sebagai langkah penerapan manajeman sampah dan pengurangan resiko yang ditimbulkan, penerapan ekonomi sirkular menjadi salah satu solusi yang dapat diterapkan. Konsep ekonomi sirkular menempatkan produksi, konsumsi dan daur ulang sampah dalam satu siklus yang dapat menurangi ekstraksi sumber daya alam, menambah lapangan kerja, mengurangi jumlah sampah yang hanya berakhir di TPA serta meningkatkan kualitas lingkungan. Ekonomi sirkular menempatkan eksploitasi sumberdaya, emisi dan limbah merupakan masalah utama. Jawaban masalah tersebut adalah sistem regeneratif yang memperlambat dan mengurangi lingkaran energi material dengan cara desain produk yang awet, perawatan, perbaikan, pembuatan ulang dan daur ulang (Geissdoerfer et al.,2017).

Menurut hasil studi pemetaan sosial yang dilakukan oleh SKK Migas - PT Pertamina Hulu Mahakam-Lapangan CPU (PT PHM-CPU) tahun 2018 di Kecamatan Anggana, isu sampah dan kebersihan lingkungan muncul sebagai permasalahan dengan tingkat urgensi tinggi. Masalah ini tidak diimbangi dengan kesadaran masyarakat, ditandai dengan pengelolaan sampah yang tidak ramah lingkungan seperti kebiasaan membuang sampah langsung di jalan, sungai dan dibakar. Merespon permasalahan ini PT PHM-CPU menginisiasi program Gerakan Bersih Kecamatan Anggana Bank Sampah Central Anggana (GBKA-BSCA) yang berfokus untuk meningkatan kesadaran masyarakat mengenai pentingnnya pengelolaan sampah rumah tangga dan penerapan PHBS. Konsep ekonomi sirkular diterapkan dengan mekanisme daur ulang sampah dan pemberdayaan perempuan melalui bank sampah. Program Corporate Social Responsibility (CSR) ini dikemas dengan nama "Betulungan Beberseh Kampong". Program ini dilaksanakan di Kecamatan Anggana, Kabupaten Kutai Kartanegara, Provinsi Kalimantan Timur, melalui kerjasama dengan Eco Wallibar, sebuah organisasi non profit atau LSM yang bergerak di bidang lingkungan. Pusat kegiatan pengolahan dan daur ulang sampah dilakukan di Workshop GBKA-BSCA.

Penelitian ini bertujuan untuk mengetahui dampak atau sebagian hasil dari 
program Betulungan Beberseh Kampong dengan mengidentifikasi perubahan perilaku penerima manfaat program pemberdayaan masyarakat tentang pengelolaan sampah dan edukasi PHBS setelah 3 tahun program berjalan.

\section{Kerangka Konseptual}

Sebagai kelompok sosial berskala lokal atau kecamatan, GBKA-BSCA dapat berperan sebagai promotor pengelolaan sampah di skala rumah tangga, perkantoran dan fasilitas umum lainnya seperti pasar, sekolah dan lain-lain dalam upaya mengurangi mismanaged waste. Sebagaimana salah satu fungsi dari lembaga lokal dalam kehidupan masyarakat yaitu sebagai suatu sistem yang turut mengatur keseimbangan untuk menciptakan harmonisasi kehidupan sosial masyarakat (Padmiati, 2013). Sampah berkaitan erat dengan kesehatan, berbagai penyakit dapat timbul dari pengelolaan sampah yang buruk. Disinilah peran Betulungan Beberseh Kampong, yaitu untuk mengedukasi serta mendorong perubahan perilaku masyarakat tentang pengelolaan sampah yang baik untuk meminimalisir efek buruk pada kesehatan dan lingkungan hidup.

Menurut Ajzen (1980) dalam teori tindakan beralasan, perilaku individu dipengaruhi oleh norma subjektif terhadap suatu tindakan. Perspektif dari lingkungan sekitar termasuk orang terdekat turut membentuk norma subjektif ini. Sikap ini dipengaruhi oleh modifying factor seperti faktor personal seperti nilai, kepribadian dan emosi; kemudian faktor sosial yaitu umur, gender, pendidikan dan keyakinan, yang terakhir ialah faktor informasi yang terdiri dari pengalaman, pengetahuan dan paparan media. Kebiasaan membuang sampah ke sungai menjadi salah satu fenomena yang didorong oleh terbentuknya norma subjektif terhadap suatu tindakan. Norma subjektif tumbuh dalam masyarakat bantaran sungai yang terbentuk dari faktor sosial seperti informasi dan pengalaman. Sebagian masyarakat Kecamatan Anggana hidup berdampingan dengan aliran Sungai Mahakam yang memungkinkan penduduknya untuk membuang sampah langsung ke sungai. Akibatnya timbunan sampah banyak ditemui disekitar kolong rumah terutama ketika air sedang surut. Tersedianya lahan yang luas dan kepadatan penduduk pemukiman yang rendah juga turut memudahkan cara pemusnahan sampah lain seperti pembakaran dan penimbunan. Kondisi ini secara turun temurun menjadi salah satu nilai yang ada di masyarakat.

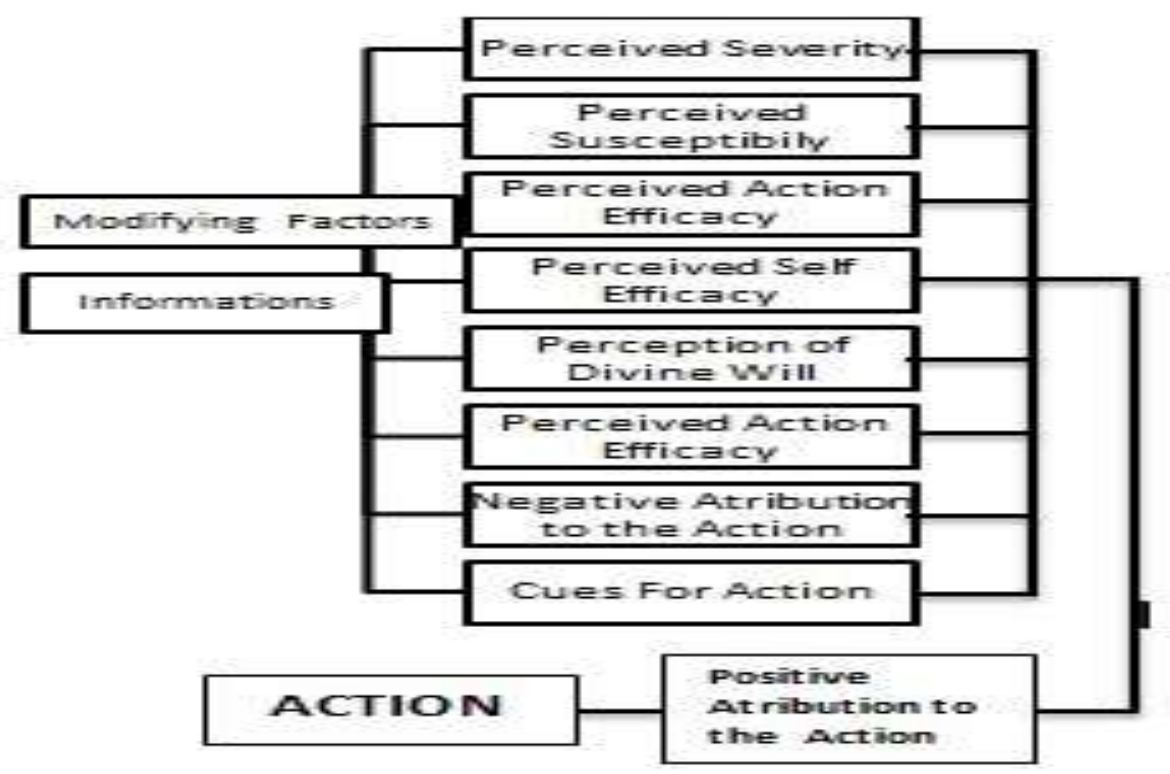

Gambar 1 The Decision Balance of Health Belief Model

Sumber: Davis Jr., Thomas P., (2004) 
Komponen pertimbangan individu dalam mengambil keputusan terkait sebuah perilaku hidup sehat dijelaskan dalam teori Health Belief Model. Buruknya sistem pengelolaan sampah di tingkat rumah tangga, personal hygiene dan perilaku hidup sehat lain dapat terbentuk dari keyakinan ancaman, keyakinan keparahan, keyakinan manfaat, persepsi penerimaan sosial, keyakinan terhadap hambatan, isyarat untuk bertindak, persepsi kehendak Tuhan, atribusi positif dan negatif dari tindakan. Teori ini menjadi landasan bagi program promosi kesehatan seperti Social Behaviour Change and Communication (SBCC). SBCC ialah salah satu strategi pendekatan yang memanfaatkan komunikasi strategis untuk mempromosikan perubahan perilaku masyarakat, kerap kali dalam bidang kesehatan dan pemberdayaan masyarakat. Strategi utama SBCC terdiri dari advokasi yaitu meningkatkan kerjasama dengan pemerintah dan organisasi lokal. Kedua, social mobilization dan terakhir behaviour change communication dengan penggunaan media sosial, mengembangkan kegiatan dalam level komunitas dan komunukasi interpersonal untuk mendorong perubahan dari level pengetahuan, sikap dan prakek diantara penerima manfaat (Davis Jr., Thomas P., 2004). Program pemberdayaan masyarakat oleh PT PHM-CPU yaitu Betulungan Beberseh Kampong, GBKABSCA, dapat dikategorikan sebagai program promosi kesehatan dalam naungan pendekatan ini.

\section{Metode Penelitian}

Penelitian ini termasuk dalam jenis kuantitatif yang dibangun dengan desain crossectional untuk mendapatkan data signifikansi dari peran program dalam upaya edukasi dan penerapan PHBS, terutama dalam pengolahan sampah, dibantu dengan angket survei sederhana dengan rancang bangun cross sectional. Desain yang digunakan ialah post test only control group design atau eksperimen sederhana dimana penerima manfaat sebagai experiment group dan kelompok warga lain sebagai control group. Apabila skor experiment group lebih tinggi daripada control group maka program Betulungan Beberseh Kampong memiliki peran dalam merubah perilaku masyarakat terkait pengelolaan sampah dan begitupun sebaliknya. Pendekatan kualitatif digunakan sebagai pelengkap untuk menggali data secara lebih dalam, serta terbuka terhadap segala pendapat dan pernyataan, tidak semata pada jawaban "ya" dan "tidak" (McCarthy, 2006). Sehingga mampu melengkapi informasi yang tidak dapat diperoleh melalui survei. Pendekatan kualitatif digunakan untuk mengidentifikasi jenis intervensi yang dilakukan oleh Program Betulungan Beberseh Kampong dan wawancara mendalam mengenai hambatan.

Instrumen dalam penelitian ini ialah kuesioner dengan 28 pertanyaan tentang pengetahuan dan perilaku kelompok kontrol dan kelompok eksperimen seputar pengelolaan sampah rumah tangga. Teknik pengumpulan data pada penelitian ini ialah dengan kuesioner, wawancara, dokumentasi dan studi literatur.

Responden dan informan berasal dari nasabah GBKA-BSCA serta warga nonnasabah yang tinggal di Desa Kutai Lama, Sungai Meriam dan Handil Terusan. Sedangkan studi literatur menelaah modul dan penelitian terhadulu mengenai Social Behaviour Change and Communication (SBCC), Teori Helath Belief Model, definisi mengenai perubahan sosial, pengukuran keberhasilan program pemberdayaan, serta upaya penanganan masalah sampah di berbagai daerah. Penelitian ini berlokasi di empat desa darat di Kecamatan Anggana, Kabupaten Kutai Kartanegara, Provinsi Kalimantan Timur. Pemilihan lokasi ini didasarkan pada tingkat homogenitas kontur lokasi empat desa tersebut yang ada di daratan, sementara 3 desa lainnya ialah desa dimana penduduknya tinggal diatas air laut

\section{Hasil dan Pembahasan Identifikasi Intervensi Program}

Pendekatan sustainable livelihood aproach (SLA) menjadi salah satu pijakan dalam pelaksanaan program. Menurut Chamber dan Conway (1991), SLA menekankan pada pengembangan kapasitas pelaku dan partisipasinya (more people-focused and 
participatory) serta menekankan adanya kerja sama partisipatoris antara masyarakat dengan institusi dan atau para pengambil kebijakan. Program Betulungan Beberseh Kampong sejalan dengan program pemerintah Kalimantan Timur yaitu Kaltim Hijau (Kaltim Green) yang merupakan sebuah program yang diinisiasi oleh Pemerintah Provinsi Kalimantan Timur yang dicanangkan oleh Gubernur Kaltim pada tahun 2010. Berangkat dari permasalahan global mengenai polusi sampah terutama sampah plastik, kemudian tumbuh kesadaran akan pentingnya mengelola sampah yang dihasilkan oleh setiap orang agar dapat menjaga kelestarian lingkungan. Secara garis besar, program ini merupakan program pengelolaan sampah berbasis masyarakat atau yang sering dikenal dengan kelompok bank sampah serta edukasi PHBS dimulai dari lingkup rumah tangga sebagai unit satuan lembaga terkecil dalam masyarakat.

Sasaran Program Betulungan Beberseh Kampong ini secara umum adalah seluruh rumah tangga daan masyarakat yang menghasilkan sampah, secara khusus diharapkan dapat menjadi alternatif tambahan penghasilan ibu-ibu rumah tangga yang tidak memiliki pekerjaan utama, dengan harapan hasil dari menabung sampah dapat menjadi sumber pemasukan tersendiri. Dalam pelaksanaannya nasabah tak hanya ibu rumah tangga, di beberapa unit bank sampah desa banyak ditemui anak-anak, warung dan sekolah yang menjadi nasabah GBKA-BSCA. Saat ini GBKA-BSCA membawahi 23 Bank Sampah unit aktif di desa-desa wilayah ring 1 dan ring 2 PT PHM - CPU yaitu empat desa di Kecamatan Anggana, yaitu Desa Sungai Meriam, Desa Kutai Lama, Desa Handil Terusan dan Desa Sidomulyo.

PT PHM - CPU berkomitmen untuk memberikan kontribusi pada pelestarian lingkungan serta pemberdayaan masyarakat di sekitar wilayah operasinya. Program Betulungan Beberseh Kampong merupakan payung besar dari usaha pengelolaan lingkungan berbasis masyarakat di Kecamatan Anggana, sedangkan GBKA-BSCA adalah nama bank sampah sentral yang melayani unit- unit bank sampah di sekitarnya. GBKA-BSCA pertama kali terbentuk pada tahun 2017 dengan nama Gerakan Sei Meriam Bersih dengan skala desa. Pelaksanaan program ini dikuatkan dengan hasil pemetaan sosial yang dilakukan PT PHM - CPU menunjukkan adanya urgensi pada pengelolaan sampah dan penerapan pola hidup sehat di tingkat kecamatan. Pada 2018 nama kelompok Gerakan Sei Meriam bersih kemudian diganti menjadi Gerakan Bersih Kecamatan Anggana untuk memperluas cakupan layanan dan gerakan dari kelompok tersebut dengan harapan dapat menebarkan manfaat kepada lebih banyak wilayah di sekitarnya.

Secara kasat mata progres sejak tahun 2018 terdapat banyak perkembangan dalam tubuh GBKA-BSCA. Saat ini GBKA-BSCA memiliki Tempat Pemilahan Sampah Terpadu atau TPST3R yang berlokasi di Desa Sei Meriam yang merupakan bantuan infrastruktur dari PT PHM - CPU dengan tanah hibah dari salah satu pengurus harian GBKA. Sampah organik dari pasar juga diolah dengan lebih baik seiring berjalannya waktu berkat inovasi dalam pengolahan kompos yang didukung oleh berbagai kegiatan pelatihan dan sarana pendukung lainnya. Saat ini telah tersedia juga Rumah Kompos sebagai pusat pengolahaan sampah organik terpadu. Selain kompos GBKABSCA juga menghasilkan bio-diesel hasil olahan limbah minyak jelantah yang digunakan untuk menggerakkan mesin diesel pencacah kompos.

Program Betulungan Beberseh Kampong dikenal oleh masyarakat dengan Gerakan Bersih Kecamatan Anggana (GBKA) saat ini aktif dikelola oleh masyarakat dengan kegiatan rutin penimbangan sampah di kelompok unit bank sampah. Dalam pelaksanaannya program ini melibatkan kelompok rentan yakni ibu-ibu rumah tangga yang tidak memiliki mata pencaharian utama. Sehingga disamping mekanisme tabungan sampah pada umumnya, Program Betulungan Beberseh Kampong berinovasi dengan melakukan pendampingan dan pelatihan pengolahan sampah plastik menjadi produk kerajinan yang diharapkan dapat dipasarkan 
untuk menambah pendapatan penerima manfaat.
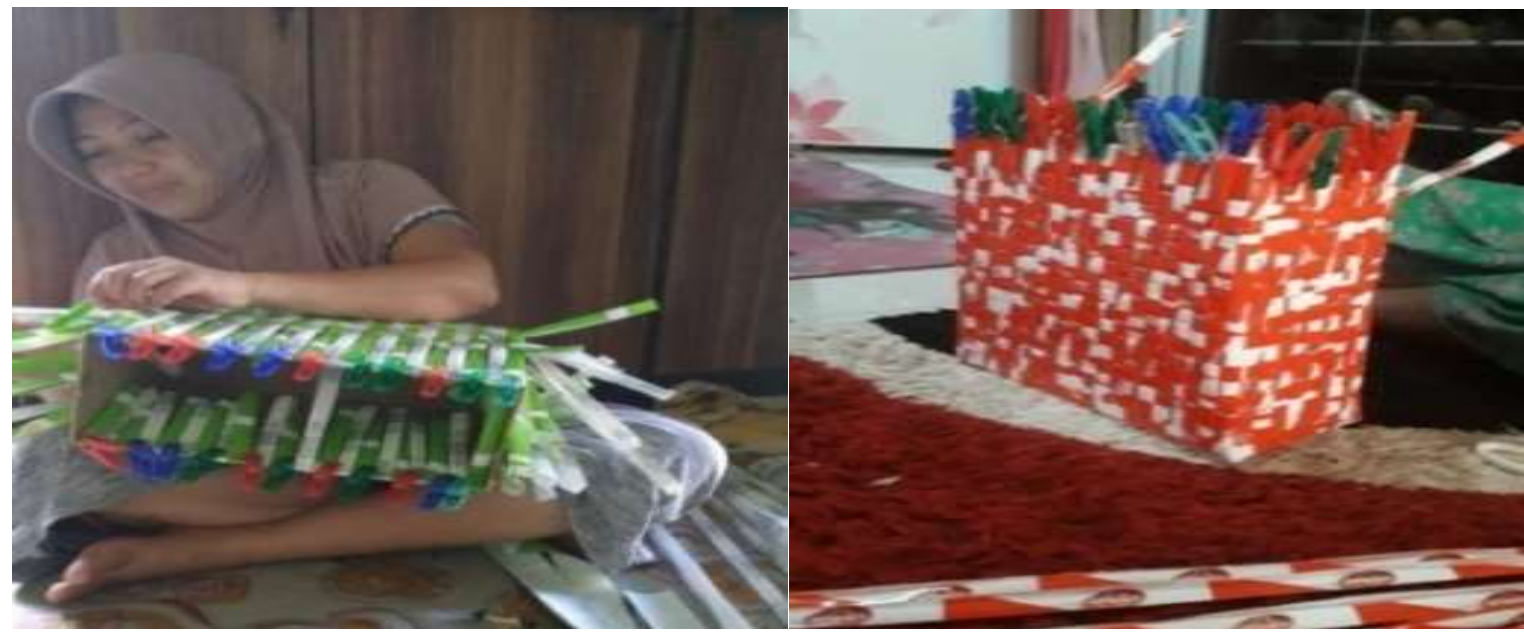

Sumber: Dokumentasi Kegiatan

\section{Gambar 2 : Produk Anyaman Daur Ulang}

GBKA-BSCA saat ini melayani 23 bank sampah unit di empat desa darat di Kecamatan Anggana dengan jumlah nasabah mencapai 560 orang. Tak hanya rumah tangga, lembaga sosial lain seperti sekolah dan kantor juga turut menjadi nasabah. Saat ini perolehan kumpulan sampah sejak Oktober 2020 sebanyak 5,93 ton sampah plastik, 5,6 ton sampah kertas dan 1,7 ton logam.

GBKA-BSCA terus berkreasi mencari peluang pengelolaan sampah. Jenis barang yang laku terjual oleh pengepul hanya jenis botol plastik, kertas dan besi bekas, kendati demikian percobaan pengolahan sampah kemasan sachet menjadi batako, gantungan kunci, campuran pondasi dan ecobrick dilakukan oleh anggota. PT PHM - CPU sebagai pendamping terbuka dengan saran dan permintaan materi pelatihan baru yang mendukung pemberdayaan masyarakat dan kontribusi positif untuk alam. Inisitaif ini tumbuh seiring dengan berkembangnya kesadaran masyarakat dalam pengelolaan sampah. Kesadaran yang kemudian berkembang menjadi rasa tanggung jawab atas zat residual yang dihasilkan oleh kegiatan hidup.

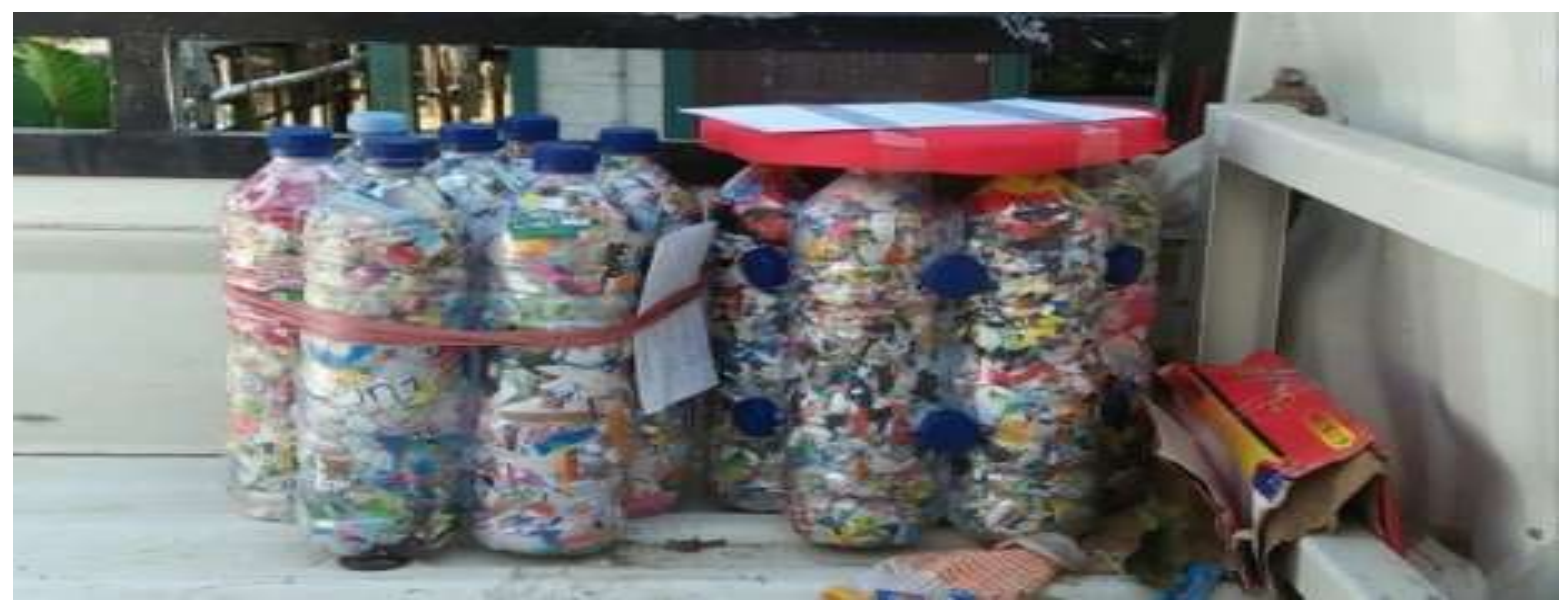

Gambar 3: Kursi Ecobrick dari 100\% Bahan Daur Ulang

Sumber: Dokumentasi Kegiatan

Mulai tahun 2020, adanya kondisi darurat pandemi covid-19 yang mengharuskan pembatasan ruang gerak pelaksanaan program secara tatap muka, sehingga beberapa kegiatan 
dilaksanakan secara daring/online. Selama masa pembatasan sosial GBKA-BSCA tak serta merta redup, himpitan kondisi mampu memunculkan demand unik seperti pembuatan tempat cuci tangan dari jerigen bekas.

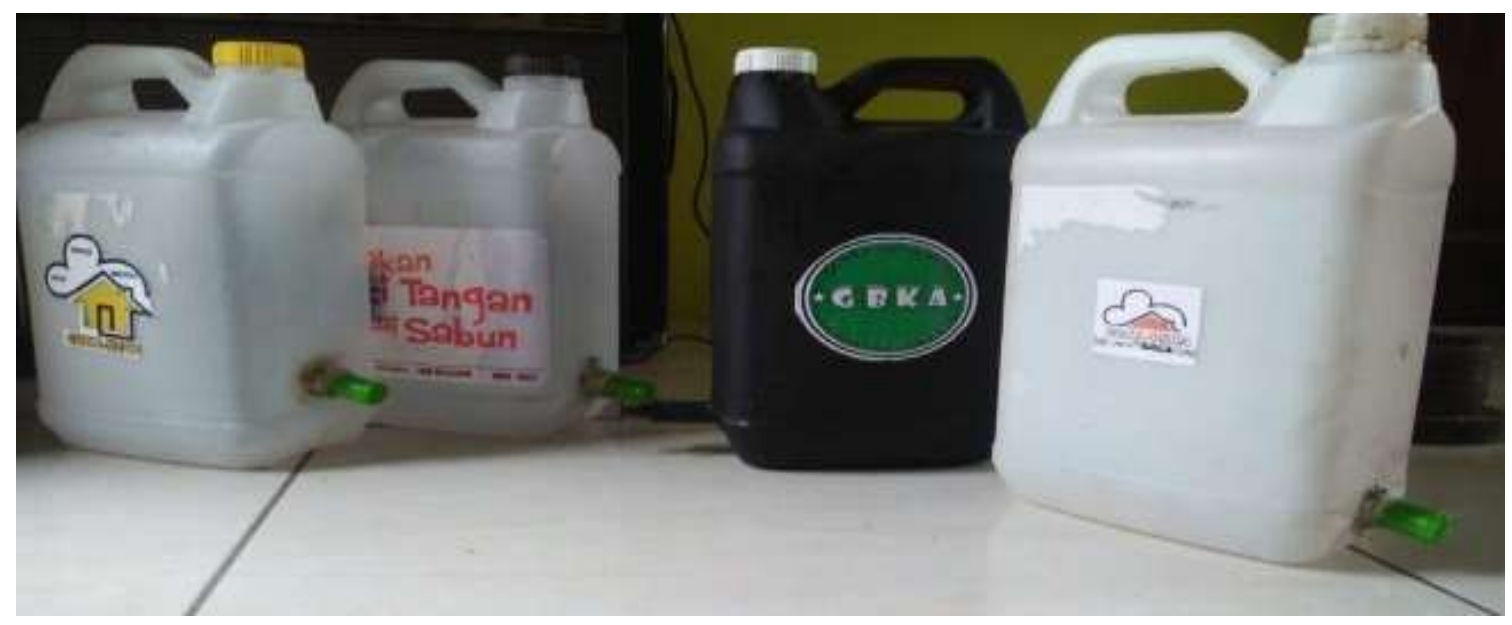

Gambar 4: Tempat Cuci Tangan dari Jerigen Bekas

Sumber: Dokumentasi Kegiatan

Sampah organik juga tak luput dari perhatian GBKA-BSCA, sampah sayur dari pasar kecamatan dan sampah rumah tangga diolah menjadi pupuk kompos. GBKS-BSCA

menjalin kerjasama dengan Pemuda Tani Mandiri Anggana untuk mengolah dan memasarkan pupuk hasil produksinya.

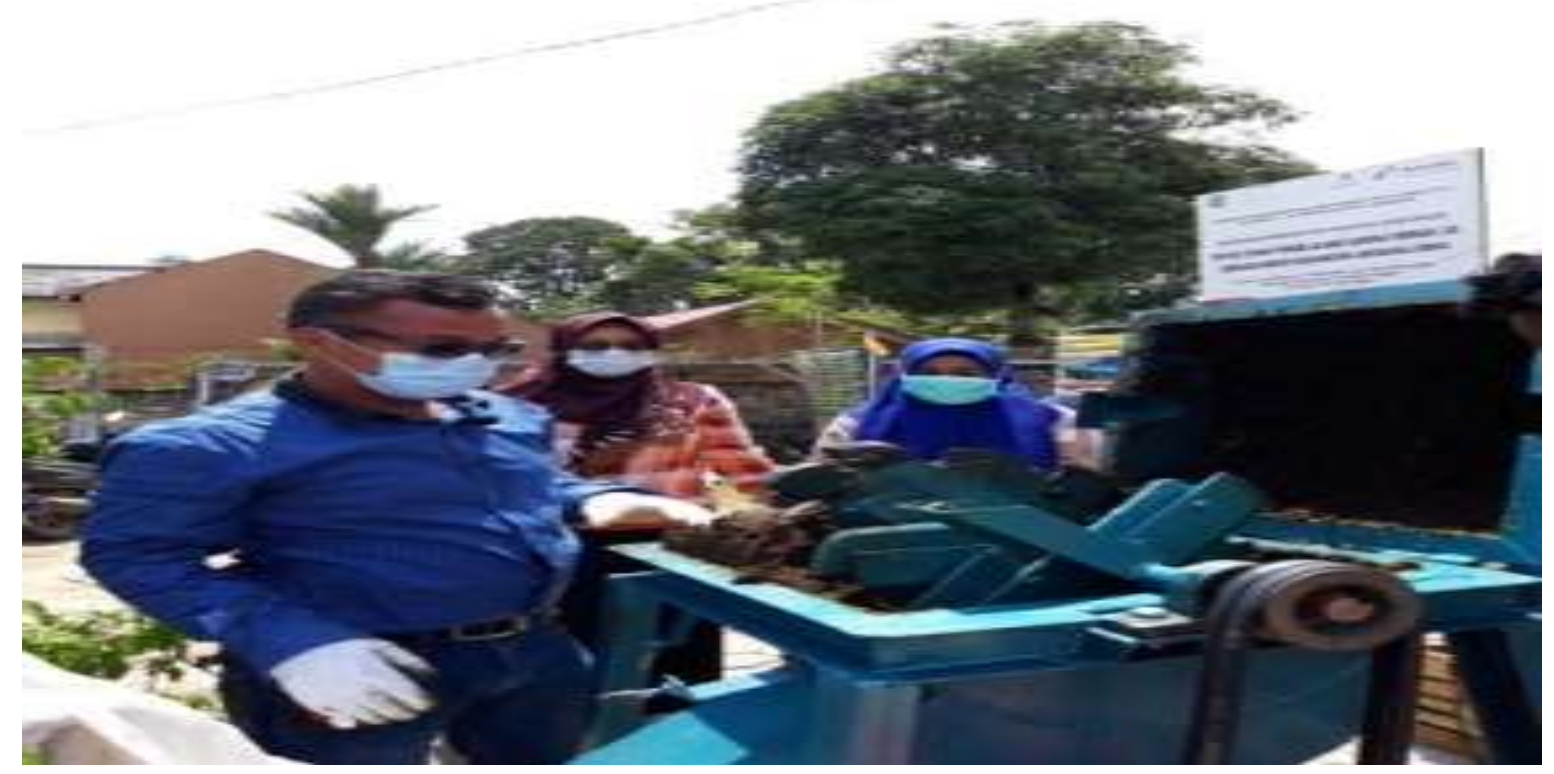

Sumber: Dokumentasi Kegiatan

Limbah minyak jelantah sebagai bahan bakar alternatif digunakan sebagai pengganti solar untuk menggerakkan mesin pencacah kompos. Minyak jelantah didapatkan dari limbah rumah tangga dan juga libah industri kecil menengah. Pembuatan biodiesel secara manual menghasilkan bahan bakar dengan nilai oktan yang rendah, dengan kualitas sedang ini sudah mampu menggerakkan mesin diesel. Pada bulan April 2021 GBKA-BSCA menghasilkan 15 liter biodiesel yang cukup untuk memenuhi kebutuhan mesin pencacah kompos selama sebulan. Output hasil produk daur ulang yang dilakukan oleh GBKA-BSCA ini saling mengisi dan menguatkan. Secara tidak langsung turut merubah rantai nilai produksi 
menjadi lebih ramah terhadap keberlanjutan ekosistem.

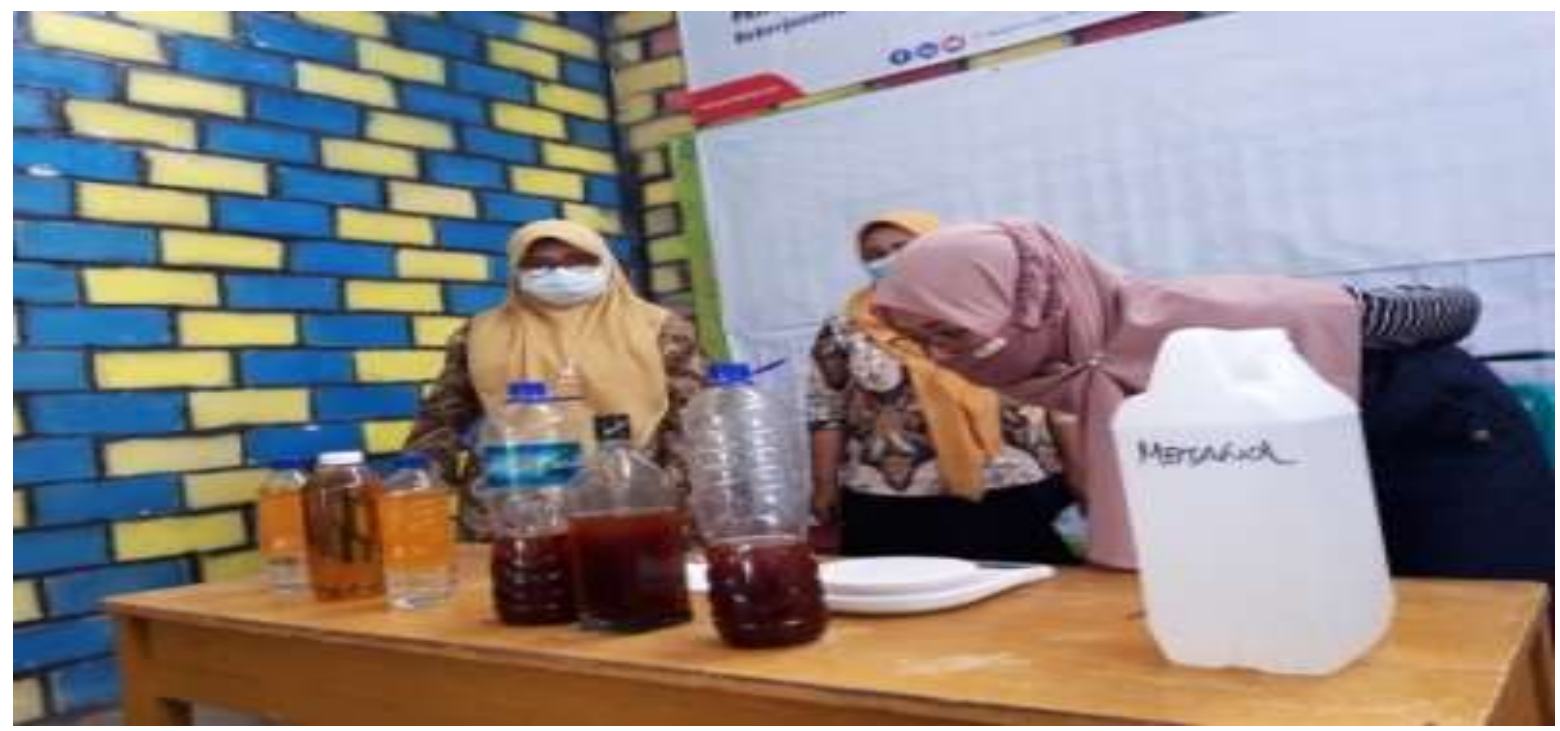

Sumber: Dokumentasi Kegiatan

\section{Gambar 6: Biodiesel dari Minyak Jelantah}

\section{Peran Program}

Data pendukung dalam penelitian melibatkan 40 responden yang dibagi merata antara antara kontrol grup dan eksperimen grup. Sejumlah $85 \%$ dari keseluruhan responden ialah perempuan, sebagaimana banyak ditemui di masyarakat Indonesia pengelolaan sampah di Kecamatan Anggana didominasi oleh perempuan yang mengindikasikan bahwa pembagian peran berbasis gender masih lekat berlaku dalam kehidupan masyarakat. Peran perempuan dalam pengelolaan sampah dilakukan secara langsung maupun tidak langsung dengan melakukan dan secara tidak langsung dengan proses edukasi dan penyadaran melalui pemberian contoh, menyuruh dan menasehati orang-orang dalam keluarganya (Muta'ali, 2003). Perempuan memiliki peranan penting dalam menjaga kualitas lingkungan hidup dengan menjadi tokoh utama pengelolaan sampah dan sosok pendidik dalam unit sosial terkecil dalam masyarakat atau keluarga.

Variabel dalam penelitian ini adalah cara pemusnahan sampah dan frekuensi pembakaran sampah diantara kelompok nasabah dan non-nasabah. Nilai yang didapat dari uji Pearson Correlation menunjukkan adanya korelasi signifikan antara kedua variabel tersebut dengan nilai 0,02 dan derajat hubungan korelasi sedang (nilai pearson correlation $0,465)$.

Hasil dari survei ditemukan adanya perbedaan perilaku cara memusnahkan sampah non organik yang signifikan antara kedua kelompok dengan nilai $p$-value 0,000 (nilai dibawah 0,05 masuk dalam kategori signifikan). 


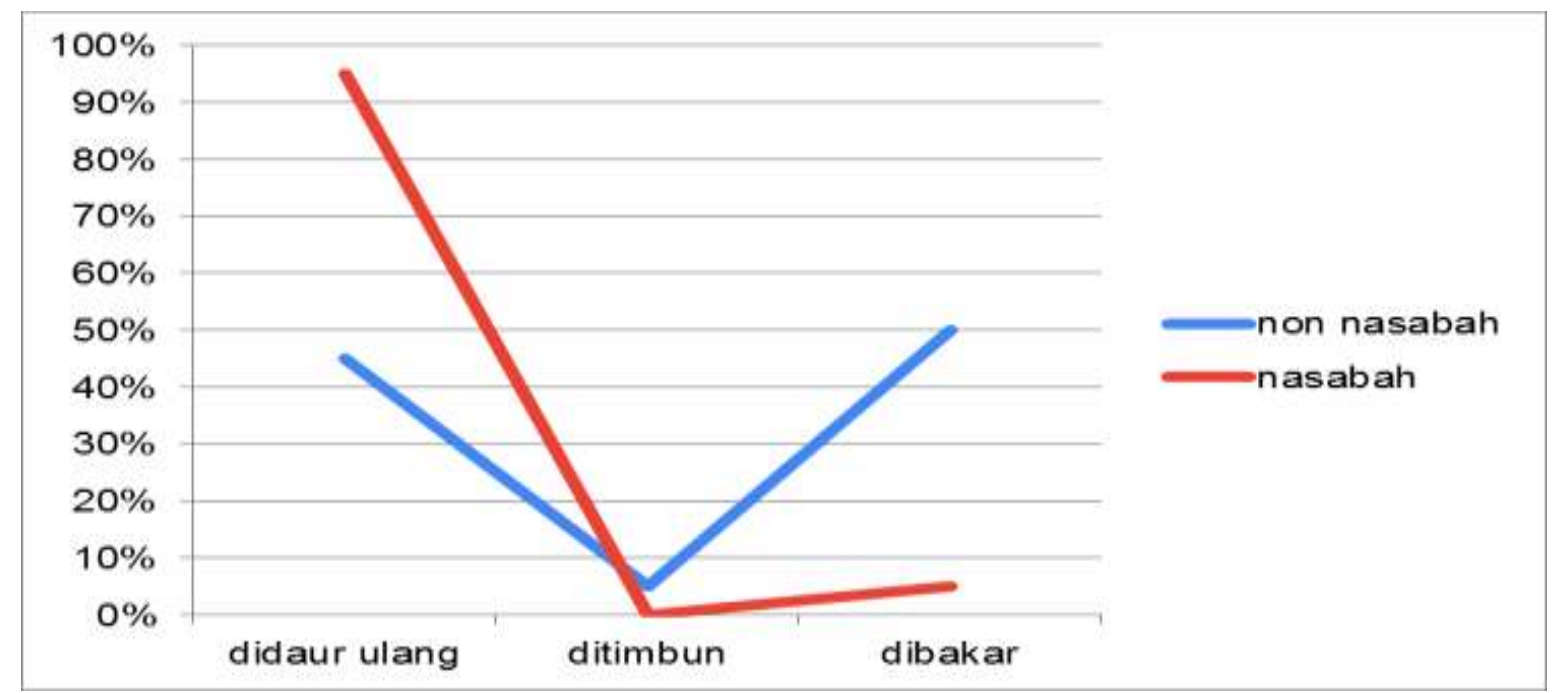

Sumber: Hasil Penelitian

\section{Grafik 1 Cara Pemusnahan Sampah Non Organik}

Perbedaan signifikan ini terlihat dari prosentase sampah yang didaur ulang oleh kelompok eksperimen sebesar 95\% sedangkan prosentase kelompok non-nasabah yang mendaur ulang sampah hanya $45 \%$. Sebagian besar dari kelompok non-nasabah memusnahkan sampahnya dengan cara dibakar, sedangkan $5 \%$ sisanya ditimbun. Faktor penghalang untuk mendaur ulang sampah salah satunya ialah kepraktisan, dimana kelompok kontrol atau non-nasabah merasa keberatan mengumpulkan sampah plastik dan kertas untuk ditimbang. Kegiatan penimbangan dilakukan satu bulan sekali, di masa tunggu inilah dimana individu merasa tidak sabar dan memilih cara pemusnahan lain yang lebih sederhana. Adanya alternatif yang lebih mudah seperti dibuang langsung ke sungai, dibakar dan dibuang langsung menjadi hambatan lain.

Kalimantan merupakan salah satu pulau terbesar di Indonesia dengan kepadatan yang tidak terlalu tinggi serta sungai-sungai besarnya, salah satunya sungai Mahakam yang merupakan sungai terpanjang di Kalimantan Timur dan bermuara di Delta Mahakam dimana muara ini terletak di Kecamatan Anggana, Kabupaten Kutai Kartanegara. Kecenderungan manusia yang membentuk populasi dan permukiman di sekitar sumber mata air termasuk aliran sungai membuat masyarakat memiliki lahan luas di sekitar rumah di bantaran sungai dapat memudahkan masyarakat untuk langsung menimbun sampah organik, membakar sampah-sampah plastik dan membuangnya ke sungai.

Hasil wawancara menunjukkan adanya fenomena khusus yang ditemui pada masyarakat yang bermukim di pinggiran sungai. Bangunan rumah panggung biasanya tertanam di pinggiran Sungai Mahakam maupun anak sungai, muka rumah menghadap ke jalan sedangkan pintu belakang rumah-rumah ini langsung menghadap ke sungai. Posisi rumah, terutama dapur, semakin memudahkan akses untuk membuang sampah langsung ke sungai. Fenomena serupa terjadi juga di bagian lain Pulau Kalimantan, pemusnahan sampah dengan cara dibuang ke sungai juga dilakukan warga Kota Samarinda yang merupakan kota yang bersebelahan dengan Kecamatan Anggana - Kabupaten Kutai Kartanegara. Kota ini memiliki kesamaan yaitu terletak di pinggiran Sungai Mahakam dimana masyarkatnya juga lebih aktif membuang sampahnya langsung ke dalam aliran sungai dan dibakar daripada dibuang ke tempat pembuangan sampah sementara yang disediakan oleh pemerintah Kota Samarinda. Peraturan Daerah Nomor 2 Tahun 2011 tentang Pengelolaan Sampah yang mengatur mengenai pengelolaan sampah menyatakan larangan pembuangan sampah ke sungai. Ancamannya dituliskan pada pasal 47 yaitu 3 bulan kurungan dan denda 50 juta, namun menurut Wibowo (2010) tidak adanya larangan tegas dan pengawasan mengenai 
penerapan peraturan tersebut serta minimnya dampak negatif yang dirasakan secara langsung oleh masyarakat membuat alternatif paling sederhana ini terus dilakukan.

Pemerintah melalui Undang Undang Nomor 18 Tahun 2008 tentang Pengelolaan Sampah menegaskan larangan membakar sampah yang tidak sesuai dengan persyaratan teknis pengolahan sampah. Pelaku pembakaran diancam denda ataupun sanksi pidana kurungan. Meski begitu pembakaran masih menjadi cara terfavorit untuk memusnahkan sampah di kalangan kelompok kontrol. Cara ini dapat dilakukan oleh rumah tangga yang tidak memiliki pekarangan luas maupun yang tidak tinggal di bantaran sungai. Pembakaran sampah yang dilakukan dalam skala rumah tangga termasuk dalam tipe pembakaran sampah terbuka, yaitu kegiatan pembakaran material secara langsung tanpa lapisan ataupun saluran cerobong sehingga hasil pembakaran secara langsung diemisikan menuju udara lepas (Estrellan dan Lino 2009). Pembakaran sampah secara terbuka banyak ditemui di negara berkembang, sementara negara-negara maju menerapkan peraturan ketat mengenai hal ini. Suhu pada pembakaran sampah terbuka berkisar antara $250-700^{\circ} \mathrm{C}$ ( atau kurang dari $2000^{\circ} \mathrm{C}$ ) yang menghasilkan pembakaran tidak sempurna. Pembakaran tidak sempurna dapat menghasilkan gas beracun karena adanya reaksi oksidasi senyawa dari material yang dibakar maupun yang ada di udara (IPCC, 2006). Pembakaran sampah dapat menambah jumlah gas-gas seperti $\mathrm{CO} 2, \mathrm{CO}, \mathrm{SO} 2, \mathrm{NO} 2$ yang dapat memicu pemanasan global melalui peningkatan produksi gas rumah kaca, kerusakan ekosistem, penipisan lapisan ozon dan hujan asam sehingga gas gas tersebut dikenal dengan sebutan gas rumah kaca. Senyawa diatas bersama formaldehida, VOC dan dioxin memiliki sifat karsinogenik atau memicu timbulnya sel-sel kanker dalam tubuh manusia dan menyebabkan gangguan saluran pernafasan.

Tabel 1 menunjukkan bahwa $85 \%$ kelompok kontrol melakukan pembakaran sampah dengan frekuensi satu minggu sekali yang artinya sangat sering dilakukan. 15\% sisanya melakukannya dengan frekuensi sedang yaitu 1 bulan sekali. Selaras dengan hasil penelitian mengenai frekuensi pembakaran sampah tingkat rumah tangga yang tidak ada pengelolaan berbasis bank sampah di Kota Depok tahun 2012, yaitu sebanyak 1,01 kali per minggu (Bestar, 2012). Sementara lebih dari separuh $(55 \%)$ individu dalam kelompok eksperimen tidak pernah membakar sampah. $45 \%$ sisanya terdistribusi dalam kategori sedang dan sering. Perbedaan signifikan frekuensi pembakaran sampah antara kedua kelompok dibuktikan dengan hasil uji Levene's Test for Equality of Variances dengan nilai $p$ value 0,000 .

Tabel 1 Frekuensi Membakar Sampah

\begin{tabular}{|l|l|l|}
\hline & \multicolumn{1}{|c|}{ Nasabah } & Non-nasabah \\
\hline tidak pernah & $55 \%$ & $0 \%$ \\
\hline 1 bulan yg lalu & $25 \%$ & $15 \%$ \\
\hline 1 minggu yg lalu & $20 \%$ & $85 \%$ \\
\hline Total & $100 \%$ & $100 \%$ \\
\hline
\end{tabular}

Sumber: Hasil Penelitian

Hampir separuh nasabah GBKA-BSCA juga masih melakukan pembakaran sampah, sementara $55 \%$ sisanya tidak pernah. Melalui hasil wawancara didapatkan informasi bahwa sebagian nasabah masih kesulitan menangani sampah sachet kemasan dan kantong kresek. Terlebih jenis sampah plastik ini tidak laku di pasaran. Cara yang ditempuh oleh $55 \%$ sisanya adalah dengan membuat kerajinan dari kemasan sachet, sedotan dan kantong plastik. Sebagian besar dari golongan ini adalah anggota UKM $3 R$ yang juga dibina oleh PT PHM - CPU yang dibentuk sebagai anak usaha dari GBKA-BSCA.

Dari survei ini juga diketahui bahwa bahwa tingkat pengetahuan masyarakat di empat desa darat Kecamatan Anggana mengenai pengelolaan sampah dan bahaya sampah 
cukup baik, tidak ada perbedaan yang sinifikan antara nasabah bank sampah dan non-nasabah (nilai $p$-value 0,19). Kelompok ini memahami bahwa sampah organik dan non organik harus dipilah dan sebagian telah melaksanakan pemilahan. Pemilahan ini dilakukan untuk memudahkan proses pembakaran atau penimbunan agar sampah organik lebih cepat busuk dan terurai.

Teori Perubahan Prochaska menyatakan bahwa perubahan perilaku individu dapat disebabkan oleh penerimaan informasi atau dorongan untuk berubah dengan frekuensi yang berbeda-beda. Perubahan dapat terjadi dengan satu kali sosialisasi dan dalam kasus lain perlu berkali-kali penyampaian pesan. Sebab individu mengalami tingkatan proses pengambilan keputusan dalam memutuskan suatu hal baru yang terdiri dari precontemplation, contenplation, preparation, action dan maintenance (Prochaska et al., 1990).

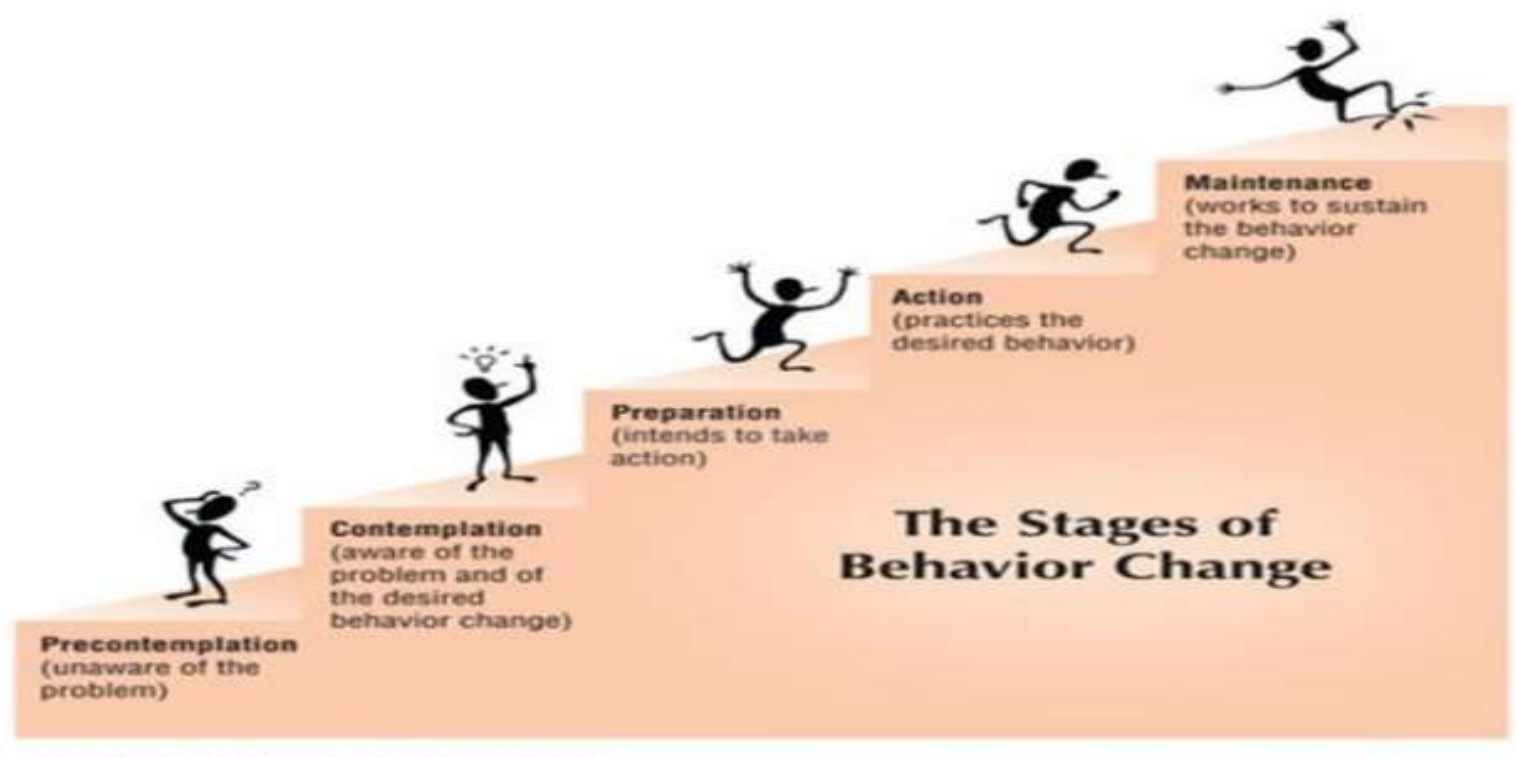

\section{Gambar 7 Tahapan Perubahan Perilaku}

Misalnya Pak Herdy (warga Desa Sungai Meriam), ia seorang individu yang siap melaksanakan setelah satu kali mendapatkan informasi dari sosialisai cara pembuatan kompos dari YouTube. Artinya ia ada di tahap action, dimana ia tak perlu banyak waktu dalam fase pre-contemplation, contemplation dan preparation. Sedangkan individu lain seperti Bu Titin (warga Desa Kutai Lama) merasa perlu menimbang dan membayangkan dirinya mengkomposkan seluruh sampah organik yang dihasilkan oleh keluarganya. la mengevaluasi kembali karena akan jauh lebih mudah baginya untuk membuangnya langsung di pekarangan belakang mengingat kepraktisan dan hasil akhirnya yang sama-sama akan terurai. Bu Titin termasuk dalam kategori individu yang membutuhkan waktu lebih lama dan perlu diyakinkan ulang, ia masih ada di fase contemplation. Seperti halnya yang dialami oleh kelompok non-nasabah yang dihadapkan oleh pilihan cara membuang sampah yang lebih mudah atau kelompok nasabah yang masih membakar sampah sisanya. Dorongan dari peer-group perlu dilakukan untuk meyakinkan. Sosio ekologikal Model menerangkan bahwa perilaku individu dan kelompok dipengaruhi oleh faktor personal seperti sikap, faktor intrapersonal yaitu pasangan, keluarga, kolega dan lingkaran pertemanan. Golongan ini mempengaruhi perilaku melalui interaksi secara langsung. Faktor dari komunitas yaitu pemimpin, petugas kesehatan, media, LSM dan pembuat kebijakan menunjukkan pengaruhnya melalui dorongan politik dan kebijakan serta kondisi ekonomi dan kondisi lingkungan alam. Ketiga faktor tersebut menjadi sumber infomasi, motivasi, kemampuan dan akses serta pembentuk norma pada seorang individu 
(Agrawal et al, 2014). Selaras seperti yang ditulis oleh Davis Jr., Thomas P., (2004) untuk Food For The Hungry tentang Barrier Analysis bahwa terdapat empat faktor yang perlu diketahui untuk menimbang tujuan sebuah program promosi kesehatan:

a. Pengetahuan bukan satu-satunya penentu seseorang dalam melakukan tindakan. Seseorang mengetahui tentang suatu tindakan jauh sebelum ia mau melakukannya

b. Jika seseorang mau melakukan suatu tindakan bukan berarti ia akan langsung melakukannya. Waktu, kesempatan, keuangan dan kepercayaan kerap menjadi penghalang

c. Menakut-nakuti tidak selamanya efektif, terkadang masalahnya ada pada ketakutan yang terlalu banyak

d. Alasan untuk melakukan perubahan tak serta merta murni untuk kesehatan, misal motivasi penggunaan sabun cuci tangan untuk tangan yang wangi dan halus bukan untuk pencegahan penyakit. Dengan kata lain perlu diberikan motivasi yang berbeda.

Nasabah dan non-nasabah adalah dua kelompok yang dibedakan dari keanggotaan mereka dalam mekainsme bank sampah. Sebagai manusia posisi keduanya masih dalam fase perubahan perilaku. Maintenance ialah tahap terakhir dalam Tahapan Perubahan Perilaku. Merujuk pada sifat masyarakat yang dinamis dan selalu berubah, harapannya dalam berdinamika nasabah dapat meningkatkan dan mempertahankan pencapaian atas kebiasaan baik seperti memilah dan menabung sampah. Lebih lanjut secara tidak langsung menjadi contoh dan menularkan kebiasaan baik ini kepada kelompok masyarakat lain.

\section{Kesimpulan}

Program Betulungan Beberseh Kampong mampu memberikan edukasi PHBS dan pelestarian lingkungan melalui promosi kesehatan dengan skema bank sampah. Sejak bulan Oktober 2021 telah terkumpul sebanyak 13 ton sampah. Hasil penelitian ini menemukan bahwa terdapat perbedaan perilaku yang signifikan perihal cara memusnahkan sampah dan frekuensi pembakaran sampah antara kelompok nasabah dan non-nasabah. Daur ulang dilakukan oleh 95\% kelompok nasabah sedangkan kelompok non-nasabah yang melakukan daur ulang hanya sebanyak $45 \%$. Pemusnahan sampah dengan cara dibakar dilakukan oleh sebagian kecil atau $5 \%$ dari kelompok nasabah, sementara kelompok nonnasabah yang melakukan pembakaran sampah sebagai cara pemusnahan utama mencapai $55 \%$. Menurut data frekuensi pembakaran sampah kelompok non-nasabah melakukan pembakaran dengan frekuensi rata-rata 1 minggu sekali. Sedangkan sebagaian dari kelompok nasabah masih melakukan pembakaran sampah meski telah melakukan daur ulang, namun dengan frekuensi yang lebih rendah dari kelompok non-nasabah. Hal ini disebabkan oleh masih adanya kesulitan menangani sampah kemasan plastik yang tidak laku dijual. Sementara 55\% lainnya menyatakan tidak pernah lagi membakar sampah. Adanya bank sampah mampu memberikan kontribusi positif berupa perubahan kebiasaan dan perubahan rantai nilai bagi nasabahnya. Manfaat tidak langsung juga diperoleh seiring dengan praktek pengelolaan sampah yang dilakukan oleh nasabah dapat memberikan contoh dan afirmasi positif kepada kelompok non-nasabah.

Dari data diatas dapat disimpulkan bahwa perubahan perilaku pengelolaan sampah masyarakat sejatinya merupakan perjalan panjang dalam mengedukasi dan meyakinkan individu dalam masyarakat. Adanya perbedaan hasil dari satu individu dan individu lainnya menandakan bahwa sebuah proses perubahan positif dalam masyarakat sedang berlangsung. Program Betulungan Beberseh Kampong sebagai institusi lokal berperan sebagai penggerak perubahan dan juga pendukung bagi masyarakat Kecamatan Anggana untuk mengelola sampah dengan baik.

Disamping itu fenomena kebiasaan masyarakat membuang sampah ke Sungai Mahakam harus ditangani bersama dengan pihak pemerintah seperti Dinas Lingkungan Hidup Kabupaten Kutai Kartangera dan Provinsi 
Kalimantan Timur untuk mendongkrak proses perubahan sosial. Undang Undang Nomor 18 Tahun 2008 tentang Pengelolaan Sampah telah jelas mengatur kriteria pembuangan sampah yang diharuskan hingga pada ancaman pelanggaran. Fakta di lapangan mengenai tidak adanya fungsi kontrol yang dilaksanakan mengindikasikan perlunya optimalisasi penerapan peran pemerintah sebagai regulator. Penghargaan Anugrah Adipura dan Kalpataru adalah contoh penerapan sistem reward yang telah diterapkan oleh pemerintah. Penerapan punishment atau pemberlakuan denda sebaimana tertulis dalam perundang undangan dan aturan di tingkat daerah juga perlu ditingkatkan untuk menimbulkan efek jera. Penyebaran informasi penerapan denda yang cenderung massif dan cepat dapat menjadi booster proses perubahan sosial.

Saran untuk penelitian selanjutnya dapat mengulik mengenai faktor-faktor penghambat perubahan perilaku masyarakat atau penerima manfaat dalam program pemberdayaan masyarakat secara psikologis dapat dianalisis lebih dalam lagi dengan menggunakan tools bernama barrier analysis. Analisis ini dapat memotret faktor penghambat keberhasilan program dari kacamata kondisi psikologis masyarakat luas. Tools ini dapat memberikan perspektif baru dalam kegiatan monitoring dan evaluasi yang selama ini berfokus pada analisis dari segi manajerial program, waktu, serta faktor eksternal lain. Alasan-alasan spesifik mengenai determinan atau faktor-faktor psikologis penerima manfaat dapat memperkaya insight sebuah program pemberdayaan. Hasil temuannya dapat bermanfaat tak hanya bagi pihak penyelenggara program pemberdayaan masyarakat namun juga menjadi insight bagi pemangku kepentingan di wilayah setempat agar menjadi bahan pertimbangan dalam perencanaan program terkait.

\section{Daftar Pustaka}

Agrawal, P.K., et al. 2014. Training Manual on Basic Monitoring and Evaluation of Social and Behavior Change Communication
Health Programs. New Delhi: Population Council

Bestar, Niknik. (2010). Studi dan Kuantifikasi Emisi Pencemar Udara Akibat Pembakaran Sampah Rumah Tangga Secara Terbuka Di Kota Depok. [Skripsi]. Universitas Indonesia

Davis Jr., dan Thomas P., (2004). Barrier Analysis Facilitator's Guide: A Tool for Improving Behavior Change Communication in Child Survival and Community Development Programs. Washington, D.C.: Food for the Hungry

Estrellan, C. R dan Lino, F. (2010). Toxic Emissions from Open Burning. Chemosphere. 80 (3): $193-147$

Fishben, Martin and Ajzen, Icek. (1980). Understanding Attitude and Predicting Social Behavior. London : Practice Hall.

Geissdoerfer, M et all,. (2017). The Circular Economy - A New Sustainability Paradigm?. Journal of Cleaner Production, 143: $753-768$

IPCC, (2006). IPCC Good Practice Guidance and Uncerttaninty Management in National Greenhouse Inventories. Electronic publication. URL: $\quad$ www.ipccnggip.iges.or.jp/public/gp/english

Jenna, R. Jambeck. (2015). Plastic waste inputs from land into the ocean. University of Georgia.

Moelyaningrum, Anita Dewi (2019). Wawancara oleh Mongabay diakses pada 30 April 2021 melalui:

www.mongabay.co.id/2019/07/03/tidakhanya-ganggu-kesehatan-sampah-jugamerusak-lingkungan/amp/

Padmiati, Etty. (2013). Menuju Masyarakat Berketahanan Sosial melalui Pemberdayaan Lembaga Sosial Lokal di 
Learning Society: Jurnal CSR, Pendidikan dan Pemberdayaan Masyarakat

Jurnal Program Studi Pendidikan Masyarakat

Universitas Mulawarman

Vol. 2 No. 1, Juni 2021. Hal: 31 - 44

Provinsi Kalimantan Tengah. Jurnal Penelitian Kesejahteraan Sosial, 12 (3): $263-275$

Prochaska, James., John Norcross., dan Carlo DiClemente (1994). Changing for Good. New York: HarperCollins

Singarimbun, M. (1981). Metode Penelitian Survai. Jakarta. LP3E

SK SNI 19-2454-1991 dan SNI 19-3242-1994.

Tata Cara Pengelolaan Sampah Perkotaan. Jakarta : Badan Penelitian dan Pengembangan Departemen Pekerjaan Umum.

Sugiyanto. (2002). Lembaga Sosial. Yogyakarta: Global Pustaka Utama

Sugiyono (2010). Metode Penelitian Kuantitatif Kualitatif dan R\&D. Bandung: Alfabeta

Wibowo, Hermawan Eko (2010). Perilaku Masyarakat Dalam Mengelola Sampah Pemukiman di Kampung Kamboja Kota Pontianak. [Thesis]. Universitas

Diponegoro 